\title{
Canola meal on starting pigs feeding
}

\section{Farelo de canola na alimentação de suínos na fase inicial}

\author{
Lina Maria Peñuela-Sierra ${ }^{1 *}$; Ivan Moreira ${ }^{2}$; Paulo Levi de Oliveira Carvalho ${ }^{3}$; \\ Juliana Beatriz Toledo ${ }^{4}$, Liliane Maria Piano Gonçalves ${ }^{4}$; Adriana Gomez Gallego ${ }^{4}$
}

\begin{abstract}
Three experiments were carried out to determine the nutritional values and evaluate the performance of piglets fed on canola meal. In experiment I, a digestibility assay was conducted using fourteen barrow pigs, with an initial body weight of $20.62 \pm 3.30 \mathrm{~kg}$. The evaluated feedstuff was canola meal, with a level of $250 \mathrm{~g} / \mathrm{kg}$ in the basal diet (corn + soybean meal-based). The experimental unit consisted of one pig, with a total of seven experimental units per diet. The values as (fed basis) of digestible (DE) and metabolizable (ME) energy of canola meal were $2,995 \mathrm{kcal} / \mathrm{kg}$ and $2,796 \mathrm{kcal} / \mathrm{kg}$, respectively. In experiment II, ileal digestibility assays were carried out to determine the apparent and true ileal digestibility coefficient and digestible amino acids. Three crossbred pigs were used, with a BW of $38.6 \pm 1.98 \mathrm{~kg}$. The treatments consisted of two diets, with a single source of protein (canola meal) and one protein-free diet (OFD). The values of digestible amino acids in canola meal were as follows: lysine: $11.8 \mathrm{~g} / \mathrm{kg}$; methionine+cystine: $9.1 \mathrm{~g} / \mathrm{kg}$; threonine: $7.9 \mathrm{~g} / \mathrm{kg}$; tryptophan: $2.4 \mathrm{~g} / \mathrm{kg}$; leucine: 15.7 $\mathrm{g} / \mathrm{kg}$; and isoleucine: $8.7 \mathrm{~g} / \mathrm{kg}$. In experiment III, 60 piglets (BW= $15.08 \pm 0.72 \mathrm{~kg}$ to $30.26 \pm 2.78 \mathrm{~kg}$ ) were allotted in a completely randomized design. The treatments consisted of four diets with increasing levels of canola meal $(50,100,150$ and $200 \mathrm{~g} / \mathrm{kg}$ ), six replicates and experimental unit consisted of two pigs. Additionally, a control diet was formulated containing $0.0 \mathrm{~g} / \mathrm{kg} \mathrm{CM}$. Regression analysis indicates that there was no effect $(\mathrm{P} \geq 0.05)$ of the level of canola meal inclusion on pigs performance. The performance results suggest that it is feasible to use up to $200 \mathrm{~g} / \mathrm{kg}$ of canola meal in starting pigs diet, without impairing performance and the feeding cost.
\end{abstract}

Key words: Digestible amino acids, digestibility, ileal cannula, protein food, performance

\section{Resumo}

Foram conduzidos três experimentos com o objetivo de determinar o valor nutricional e avaliar o desempenho de leitões alimentados com farelo de canola (FC). No Experimento I foi conduzido um ensaio de digestibilidade total com 14 suínos mestiços de linhagem comercial, machos castrados, com $20,32 \pm 3,30 \mathrm{~kg}$ de PV inicial. O alimento teste foi o farelo de canola, com o nível de $250 \mathrm{~g} / \mathrm{kg}$ na ração referência (milho + farelo de soja). Cada suíno constituiu uma unidade experimental, totalizando sete unidades experimentais por ração. Os valores de energia digestível (ED) e energia metabolizável (EM) na matéria natural para o FC foram $2995 \mathrm{kcal} / \mathrm{kg}$ e $2796 \mathrm{kcal} / \mathrm{kg}$ respectivamente. No Experimento II foi conduzido um ensaio para determinar os coeficientes de digestibilidade ileal aparente e verdadeira $\mathrm{e}$ aminoácidos digestíveis. Foram utilizados três suínos canulados com 38,6 1,98 kg de PV. Os tratamentos consistiram em duas dietas, uma dieta contendo FC como única fonte de proteína e uma dieta isenta de

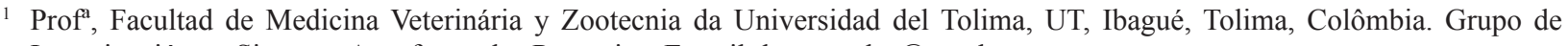
Investigación en Sistemas Agroforestales Pecuarios. E-mail: lmpenuelas@ut.edu.co

2 Prof., Dept ${ }^{\circ}$ de Zootecnia, Universidade Estadual de Maringá, UEM, Maringá, PR, Brasil. E-mail: imoreira@uem.br

3 Prof., Dept ${ }^{\circ}$ de Zootecnia, Universidade Estadual do Oeste do Paraná, UNIOESTE, Marechal Cândido Rondon, PR, Brasil. E-mail: paulolevi@yahoo.com.br

4 Discentes do Curso de Mestrado ou Doutorado, Programa de Pós-Graduação em Zootecnia, UEM, Maringá, PR, Brasil. E-mail: juliana.b.toledo@gmail.com; liliane_piano@hotmail.com; adritonyv@yahoo.es

Author for correspndence 
proteína. Os valores de aminoácidos digestíveis do FC foram: lisina: $11,8 \mathrm{~g} / \mathrm{kg}$, metionina+cistina: 9,1 $\mathrm{g} / \mathrm{kg}$ e treonina: $7,9 \mathrm{~g} / \mathrm{kg}$, triptofano: $2,4 \mathrm{~g} / \mathrm{kg}$; leucina: $15,7 \mathrm{~g} / \mathrm{kg}$ e isoleucina: $8,7 \mathrm{~g} / \mathrm{kg}$. No Experimento III foram utilizados 60 leitões, com peso vivo inicial de $15,08 \pm 0,72 \mathrm{~kg}$ e final de $30,26 \pm 2,78 \mathrm{~kg}$, distribuídos em delineamento experimental inteiramente casualizados. Os tratamentos consistiram em quatro dietas com níveis de inclusão de FC $(50,100,150$ e $200 \mathrm{~g} / \mathrm{kg})$, com seis repetições e dois suínos por unidade experimental. Adicionalmente, foi formulada uma ração testemunha (RT), contendo $0 \%$ de FC. A análise de regressão indicou que não houve efeito $(\mathrm{P} \geq 0,05)$ do nível de inclusão do FC sobre o desempenho. Os resultados de desempenho sugerem que é viável a utilização em até $200 \mathrm{~g} / \mathrm{kg}$ de FC nas rações, sem prejuízos no desempenho e no custo com a alimentação.

Palavras-chave: Alimento proteico, aminoácido digestível, cânula ileal, desempenho, digestibilidade

\section{Introduction}

Economically, feeding represents about $70 \%$ of pig production cost, and is therefore an aspect that demands attention from nutritionists and producers, requiring alternative food sources that can reduce the production cost of the system. Considering that pigs in Brazil usually consume diets based on corn and soybean meal ( 75 to $80 \%$ of feed), resulting in high cost inputs because they are also used in human food (JOHNSTON et al., 2003), research must be performed to find more affordable alternative food.

Canola is a rapeseed variety that is genetically selected to contain low levels of glucosinolates and erucic acid (SORREL; SHURSON, 1990); it is mainly used for oil production, resulting as a co-product of the extraction of canola meal (CM). $\mathrm{CM}$ has a high content of crude protein ranging from 350 to $400 \mathrm{~g} / \mathrm{kg}$ (NÄSI; SILJANDER-RASI, 1991) and is characterized by lower amounts of lysine and a high content of sulfur-containing amino acids (methionine and cystine) compared to bran soybean (CASTELL; CLIPLEF, 1993). According to Thacker and Newkirk (2005), CM has been an acceptable protein source for inclusion in pig diets, and is commonly used in Canada and Europe.

According to Gomes et al. (1991), in southern Brazil, canola oil has been produced since 1992, with high production mainly in Paraná. Thus, CM as a co-product of this process is the basis of study for research into alternative feedstuffs in order to reduce the cost of animal feeding.

The chemical composition suggests that $\mathrm{CM}$ can be used in diets for pigs. According to Bell and
Keith (1991), CM contains: 3,100 kcal DE/kg, 2,900 $\mathrm{kcal} \mathrm{ME} / \mathrm{kg}, 377 \mathrm{~g} / \mathrm{kg} \mathrm{CP} ; 21.6 \mathrm{~g} / \mathrm{kg}$ Lysine; $118 \mathrm{~g} /$ $\mathrm{kg} \mathrm{CF} ; 6.3 \mathrm{~g} / \mathrm{kg} \mathrm{Ca}$, and $10.1 \mathrm{~g} / \mathrm{kg}$ P. However, the NDF content of CM is higher compared to soybean meal, due to the seed coat present in the bran, which causes the energy content of $\mathrm{CM}$ to be lower than that of soybean meal $(2,600$ vs. $3,400 \mathrm{kcal} / \mathrm{kg})$, respectively (BELL, 1993). The amino acid profile of CM is similar to soybean meal (MOREIRA et al., 1996), but contains lower levels of lysine and higher levels of methionine+cystine.

For the optimal development of the pork production chain, a precise study of the amino acid requirements for maintenance, growth and animal production, as well as an adequate supply of these amino acids from feedstuffs is essential (WILLIAMS, 1995). Therefore, it is important to know the nutritional value of feedstuffs and the amount of true digestible amino acids in order to accurately formulate diet aiming the maximum performance and minimizing losses.

This study was carried out aiming to evaluate the nutritional value of canola meal and its effects on piglet performance, as well as its economic feasibility.

\section{Materials and Methods}

The experiments were performed at experimental the Pig Barn in Fazenda Experimental de Iguatemi, at Universidade Estadual de Maringá (CCA/UEM), located in the State of Paraná, Brazil $\left(23^{\circ} 21^{\prime} \mathrm{S}, 52^{\circ}\right.$ 04' W, 564 m). 
In this study, three experiments were conducted: a total digestibility assay (Experiment I), ileal digestibility assay (Experiment II) and a performance assay (Experiment III) using starting pigs $(15-30 \mathrm{~kg})$.

The chemical composition and energy value of the canola meal (Table 1), diets and feces were determined at the Animal Nutrition Laboratory
(UEM). The analyses of dry matter, crude protein, ash, calcium and total phosphorus were performed according to the procedures described by Silva and Queiroz (2002). The analysis of total essential and non-essential amino acids (Table 5) was performed using HPLC, according to the AOAC (1990) methodology, at CBO Laboratory Analysis (Campinas - SP).

Table 1. Chemical and energetic composition of canola meal (as-fed-basis).

\begin{tabular}{lc}
\hline Item & Canola meal $(\mathrm{g} / \mathrm{kg})$ \\
\hline Dry matter & 891.70 \\
Gross energy, kcal/kg & $4,283.00$ \\
Crude protein & 345.90 \\
Crude fiber & 72.00 \\
Neutral detergent fiber & 297.00 \\
Acid detergent fiber & 204.00 \\
Crude fat & 39.00 \\
Calcium & 5.90 \\
Total phosphorus & 10.00 \\
Available phosphorus & 2.10 \\
Organic matter & 828.00 \\
Total carbohydrates & 550.00 \\
Nonfiber carbohydrates & 250.00 \\
\hline
\end{tabular}

The total digestibility trial was carried out using 14 crossbred barrows from a commercial line with an initial average weight of $20.62 \pm 3.30 \mathrm{~kg}$. The animals were kept individually in metabolism cages similar to those described by Pekas (1968) in a temperature-controlled room. The ambient, average minimum temperature was $21.3 \pm 0.75^{\circ} \mathrm{C}$ and the average maximum was $23.8 \pm 0.90^{\circ} \mathrm{C}$; the average minimum relative humidity was $38.9 \pm 12.32 \%$, and the average maximum was $60.8 \pm 12.45 \%$.

The basal diet consisted of corn $(704.2 \mathrm{~g} / \mathrm{kg})$, soybean meal $(264.0 \mathrm{~g} / \mathrm{kg})$, salt $(6.0 \mathrm{~g} / \mathrm{kg})$, limestone $(15.8 \mathrm{~g} / \mathrm{kg})$, dicalcium phosphate $(5.0 \mathrm{~g} / \mathrm{kg})$ and mineral-vitamin premix $(5.0 \mathrm{~g} / \mathrm{kg})$, which had been formulated to meet the requirements described by Rostagno et al. (2005).
Canola meal was tested, by replacing $250 \mathrm{~g} / \mathrm{kg}$ of the reference diet in one test diet. The experimental period was 16 days (eleven days for adaptation and five days for total feces and urine collection).

Feed supply and feces and urine collection were performed according to Sakomura and Rostagno (2007). During the collection period, the feed supply was calculated based on metabolic weight $\left(\mathrm{kg}^{0.75}\right)$ from each pig and on the average feed intake recorded in the pre-experimental phase. Feeding was offered at $08 \mathrm{~h}$ and $14 \mathrm{~h}$, with $55 \%$ of the total in the morning and $45 \%$ in the afternoon. All diets were moistened with approximately $20 \%$ water to avoid waste, reduce dust and improve feed intake by the animals. After each meal, water was provided at a rate of $3 \mathrm{~mL}$ of water/g of diet. 
To mark the start and end of the total feces collection period, $3 \% \mathrm{Fe}_{3} \mathrm{O}_{2}$ was used as a marker. Feces were collected once a day, packed in plastic bags and stored in a freezer $\left(-18^{\circ} \mathrm{C}\right)$. Subsequently, the material was thawed, homogenized and dried (approximately $350 \mathrm{~g}$ ) in a forced-ventilation oven at $55^{\circ} \mathrm{C}$ for $72 \mathrm{~h}$. The material was then ground in a knife mill (1 mm sieve). The urine was collected in plastic buckets containing $20 \mathrm{~mL}$ of $\mathrm{HCl}(1: 1)$ to prevent bacterial proliferation and possible volatility losses.

The digestibility coefficients of dry matter (DCDM), of gross energy (DCGE), of crude protein (DCCP) and of organic matter (DCOM) of the canola meal were calculated according to Matterson et al. (1965); the values for digestible dry matter (DDM), digestible protein (DP), digestible organic matter (DOM), digestible energy (DE) and metabolizable energy (ME) were obtained.
Experiment II, was conducted to assess ileal digestibility using three crossbred pigs from a commercial line with an initial average body weight of $38.6 \pm 1.98 \mathrm{~kg}$; these animals were submitted to surgery for implantation of a T-cannula, as described by Bellaver (1989) and Souza (2003). After the surgery, the animals were transferred to individual concrete pens ( $\left.3.80 \mathrm{~m}^{2} / \mathrm{each}\right)$, with a nipple drinker at the back and semi-automatic feeders at the front, which provided free access to feed and water. These animals were placed in recovery for 20 days. Surgical and postoperative procedures were approved by the Committee of Ethical Conduct in the Use of Animals in Experiments from Universidade Estadual de Maringá.

The treatment consisted of one diet with a single source of protein food (CM) and one-protein-free diet (OFD) in order to estimate endogenous amino acid losses (Table 2). Ground rice husk was used as a fiber source, which had $2.0 \mathrm{~g} / \mathrm{kg} \mathrm{CP}$ considered unavailable; $5.0 \mathrm{~g} / \mathrm{kg}$ chromium oxide $\left(\mathrm{Cr}_{2} \mathrm{O}_{3}\right)$ was added to the diets as a marker.

Table 2. Centesimal composition of experimental diets used on ileal digestibility assay.

\begin{tabular}{lcc}
\hline \multirow{2}{*}{ Ingredients $(\mathrm{g} / \mathrm{kg})$} & \multicolumn{2}{c}{ Diets } \\
\cline { 2 - 3 } & One protein-free diet & Canola meal \\
\hline Canola meal & 0.00 & 350.00 \\
Starch & 501.40 & 360.60 \\
Sugar & 428.20 & 255.00 \\
Ground rice husk & 20.00 & 0.00 \\
Limestone & 7.00 & 2.80 \\
Dicalcium phosphate & 12.40 & 10.10 \\
Soybean oil & 20.00 & 10.00 \\
Sodium chloride & 3.00 & 3.50 \\
Vitamin and mineral premix $^{1}$ & 3.00 & 3.00 \\
Chromium oxide & 5.00 & 5.00 \\
\hline
\end{tabular}

${ }^{1}$ Vitamin and mineral premix for growing pigs.

The CM was evaluated using three cannulated pigs and four experimental periods. The experiment lasted for six days, with five days of adaptation (determination of feed intake and regulation of intestinal flow) and one day of digesta collection. The following periods consisted of three days of adaptation and one day of digesta collection. In another period of six days (five days of adaptation and one day digesta collection), the same procedure was carried out to determine the excretion of endogenous amino acids and proteins, using the protein-free diet. 
Digesta samples were harvested in polyethylene bags, attached to the cannula and were subsequently put into plastic pots which were identified and put into the freezer $\left(-5^{\circ} \mathrm{C}\right)$ until the end of the collection period in order to avoid amino acid degradation. At the end of this period, the samples were defrosted, weighed, mixed and lyophilized. Dried samples were ground, and packaged in glass flasks with lids for future analysis.

Levels of chromium oxide and DM in the digests were determined according to the methods described by Silva and Queiroz (2002). The contents of amino acids in the diets and digesta samples were determined by HPLC in the CBO Laboratory Analysis in Campinas, Brazil.

The ileal digestibility of amino acids was calculated based on the levels of chromium $(\mathrm{Cr})$ in the diets and digesta of pigs; this was performed by calculating the indigestibility factor (IF) using the formulae described by Sakomura and Rostagno (2007).

To determine the coefficients of SID amino acid digestibility of the $\mathrm{CM}$, the values of endogenous amino acid losses were used from the animals that received OFD.

In experiment III, 60 crossbred pigs (30 barrows and 30 gilts) were used from a commercial line with an initial average body weight of $15.8 \pm 0.72$ and a final weight of $30.26 \pm 2.78 \mathrm{~kg}$. The ambient, average minimum temperature was $18.5 \pm 1.97^{\circ} \mathrm{C}$ and the maximum was $28.8 \pm 3.43^{\circ} \mathrm{C}$.

The chemical composition (Table 1), energetic value (Table 4) and amino acid composition (Table 5) of canola meal were used for the diet formulations. For the corn and soybean meal, the chemical composition was analyzed in the Animal Nutrition Lab (UEM). The digestible amino acids values of corn and soybean meal were those reported by Rostagno et al. (2005) corrected for crude protein.

Diets and water were given ad libitum throughout the experimental period. Diets based on corn and soybean meal (Table 3) were formulated to meet the requirements outlined by Rostagno et al. (2005) for starting pigs.
Pigs were allotted using a randomized design with four treatments and six replicates. Each experimental unit consisted of two pigs. Additionally, a control diet was formulated (CD) containing $0.0 \mathrm{~g} / \mathrm{kg} \mathrm{CM}$.

At the beginning (baseline) and at end of the experimental period, blood samples were harvest via the cranial vena cava, as described by Cai et al. (1994), for the subsequent analysis of plasma urea nitrogen (PUN). PUN values were determined using the Urea kit from "Gold Analisa Diagnóstica Ltda". The values obtained at the beginning of the experiment were used as covariables in the statistical analysis.

Blood samples were centrifuged $(3,000 \mathrm{rpm}$ for $15 \mathrm{~min}$ ) to obtain the plasma. Then, $3 \mathrm{~mL}$ of plasma (in duplicate) was transferred to Eppendorf tubes that were properly identified and stored in a freezer $\left(-18^{\circ} \mathrm{C}\right)$ for further analysis at the Animal Nutrition Lab at Maringá State University.

To evaluate the economic feasibility of CM, market prices of raw materials were obtained and the cost of feed per kilogram of weight gain was calculated, according to Bellaver et al. (1985). The economic and cost efficiency indicators were also calculated, following the methodology proposed by Gomes et al. (1991). The prices of the raw materials used to calculate the costs of the experimental diets were: corn grain, R\$ $0.485 / \mathrm{kg}$; soybean meal, $\mathrm{R} \$$ $0.598 / \mathrm{kg}$; soybean oil, R\$2.63/kg; and canola meal, $\mathrm{R} \$ 0.466 / \mathrm{kg}$.

The results for the studied variables were submitted to analysis of variance (ANOVA) in accordance with the following statistical model: $\mathrm{Y}_{i j}$ $=\mu+\mathrm{b}_{1}\left(\mathrm{~N}_{i}-\mathrm{N}\right)+\mathrm{b}_{2}\left(\mathrm{~N}_{i}-\mathrm{N}\right)+\mathrm{LF}+\mathrm{e}_{i j}$, where $\mathrm{Y}_{i j}=$ observed value of the variables for each individual $j$, receiving the level $i$ of $\mathrm{CM} ; \mu=$ the constant associated with all observations, $b_{1}=$ linear regression coefficient of the level of CM on variable $\mathrm{Y} ; \mathrm{b}_{2}=$ quadratic regression coefficient of the level of CM on variable $\mathrm{Y} ; \mathrm{N}_{i}=$ levels of $\mathrm{CM}$ in the feed, where $i=50,100.150$ and $200 \mathrm{~g} / \mathrm{kg} ; \mathrm{N}=$ average $\mathrm{CM}$ in the feed; $\mathrm{LF}=$ lack of fit, and $\mathrm{e}_{i j}=$ random error associated with each observation. 
Table 3. Centesimal, chemical and energy composition of diets containing increasing levels of canola meal for starting pigs $(15-30 \mathrm{~kg})$ feeding.

\begin{tabular}{|c|c|c|c|c|c|}
\hline \multirow[b]{2}{*}{ Items } & \multicolumn{5}{|c|}{ Inclusion levels of canola meal $(\mathrm{g} / \mathrm{kg})$} \\
\hline & 0 & 50 & 100 & 150 & 200 \\
\hline Corn & 709.50 & 675.50 & 641.50 & 614.20 & 598.20 \\
\hline Soybean meal & 245.80 & 226.50 & 207.10 & 180.80 & 142.90 \\
\hline Canola meal & 0.00 & 50.00 & 100.00 & 150.00 & 200.00 \\
\hline Dicalcium phosphate & 17.90 & 17.60 & 17.30 & 17.00 & 16.80 \\
\hline Limestone & 5.20 & 4.80 & 4.40 & 4.00 & 3.60 \\
\hline Sodium chloride & 4.00 & 4.00 & 4.00 & 4.00 & 4.00 \\
\hline Soybean oil & 7.40 & 11.70 & 16.10 & 20.20 & 23.70 \\
\hline Vitamin and mineral premix ${ }^{1}$ & 5.00 & 5.00 & 5.00 & 5.00 & 5.00 \\
\hline Growth promoter & 0.05 & 0.05 & 0.05 & 0.05 & 0.05 \\
\hline L-lysine HCL (79\%) & 3.40 & 3.30 & 3.20 & 3.40 & 3.80 \\
\hline DL-methionine, (99\%) & 0.80 & 0.70 & 0.50 & 0.50 & 0.50 \\
\hline L-threonine, $(95 \%)$ & 0.90 & 0.90 & 0.90 & 0.90 & 1.10 \\
\hline L-tryptophan, HCL (98\%) & 0.00 & 0.00 & 0.00 & 0.01 & 0.13 \\
\hline \multicolumn{6}{|l|}{ Calculated Values $^{2}$} \\
\hline Metabolizable energy, $\mathrm{Kcal} / \mathrm{kg}$ & $3,230.00$ & $3,230.00$ & $3,230.00$ & $3,230.00$ & $3,230.00$ \\
\hline $\mathrm{NDF}, \mathrm{g} / \mathrm{kg}$ & 108.70 & 117.70 & 126.60 & 135.60 & 145.0 \\
\hline $\mathrm{ADF}, \mathrm{g} / \mathrm{kg}$ & 45.20 & 52.50 & 59.90 & 66.80 & 73.10 \\
\hline Lysine, $\mathrm{g} / \mathrm{kg}$ & 9.90 & 9.90 & 9.90 & 9.90 & 9.90 \\
\hline Methionine + cystine, $\mathrm{g} / \mathrm{kg}$ & 5.50 & 5.50 & 5.50 & 5.50 & 5.50 \\
\hline Threonine, $\mathrm{g} / \mathrm{kg}$ & 6.20 & 6.20 & 6.20 & 6.20 & 6.20 \\
\hline Tryptophan, g/kg & 1.70 & 1.70 & 1.70 & 1.70 & 1.70 \\
\hline Calcium, $\mathrm{g} / \mathrm{kg}$ & 7.20 & 7.20 & 7.20 & 7.20 & 7.20 \\
\hline Available phosphorus, $\mathrm{g} / \mathrm{kg}$ & 4.00 & 4.00 & 4.00 & 4.00 & 4.00 \\
\hline
\end{tabular}

${ }^{1}$ Vitamin and mineral premix for starting pigs; ${ }^{2}$ Calculated based on Rostagno et al. (2005) and/or determined.

The degrees of freedom for each CM level were decomposed into orthogonal polynomials to obtain the regression equations. To compare the results of the control diet (without CM) with each CM level, the Dunnett test was applied (SAMPAIO, 1998). All statistical analyses were performed using the statistical and gene analysis system SAEG (Sistema para Análises Estatísticas e Genéticas, version 7.1). In the performance experiment, the initial weight of the piglets was used as a co-variable.

\section{Results and Discussion}

The chemical and total amino acids composition of CM (Table 1 and Table 5) are different to those cited by Rostagno et al. (2011) for the levels of crude protein $(379.7 \mathrm{~g} / \mathrm{kg})$, crude fiber $(72 \mathrm{~g} / \mathrm{kg})$, lysine
$(20.1 \mathrm{~g} / \mathrm{kg})$, met+cys $(16.4 \mathrm{~g} / \mathrm{kg})$ and threonine $(15.7 \%)$. The values of dry matter $(89.29 \mathrm{~g} / \mathrm{kg})$ and gross energy (GE) $(4,283 \mathrm{kcal} / \mathrm{kg})$ reported by these authors were similar to those observed in the current study.

The CM showed the content of DM, crude protein, total amino acids and gross energy (Table 1) to be smaller than those cited by Woyengo et al. (2010) and Seneviratne et al. (2010), who reported values of $895.2 \mathrm{~g} / \mathrm{kg}$ and $956 \mathrm{~g} / \mathrm{kg} \mathrm{DM}, 417.7 \mathrm{~g} / \mathrm{kg}$ and $385 \mathrm{~g} / \mathrm{kg} \mathrm{CP} ; 21.8$ and $24.2 \mathrm{~g} / \mathrm{kg}$ lysine; 15 and $15.9 \mathrm{~g} / \mathrm{kg}$ met+cys; $5,030 \mathrm{Kcal} / \mathrm{kg}$ and 4,812 kcal/ $\mathrm{kg}$ of GE, respectively.

The values of total amino acids of CM (Table 5) were similar to those reported by Rojo et al. (2001), who found values of lysine $(19.6 \mathrm{~g} / \mathrm{kg})$, threonine 
(15.5 g/kg), tryptophan (4.6 g/kg), met+cys (16.4 $\mathrm{g} / \mathrm{kg})$, isoleucine $(13.8 \mathrm{~g} / \mathrm{kg})$ and leucine $(25.2 \mathrm{~g} /$ $\mathrm{kg}$ ) in the data studied with a compilation of 171 aminograms of CM.

When the results of the digestibility coefficients and digestible nutrients obtained in experiment I (Table 4) were compared to the values reported by
Rostagno et al. (2011), similar values of DCOM (0.730), DE and $\mathrm{ME} \mathrm{(3,019} \mathrm{and} \mathrm{2,787} \mathrm{kcal/kg,}$ respectively), digestible organic matter $(609.2 \mathrm{~g} / \mathrm{kg})$ and digestible protein $(286.2 \mathrm{~g} / \mathrm{kg})$ were observed. The value of DCCP was higher in this study in comparison to the values reported by Rostagno et al. (2011), who indicated a level of 0.751 .

Table 4. Digestibility coefficients and values of digestible nutrients of canola meal in starting pigs (15 to $30 \mathrm{~kg})$.

\begin{tabular}{lc}
\hline Digestibility coefficients $(\mathrm{g} / \mathrm{g})$ & Canola meal \\
\hline Dry matter & 0.613 \\
Gross energy & 0.699 \\
MC gross energy & 0.653 \\
Crude protein & 0.880 \\
Organic matter & 0.709 \\
\hline Digestible nutrients & As fed basis \\
\hline Digestible dry matter, g/kg & 546.90 \\
Digestible energy, Kcal/kg & $2,995.00$ \\
Metabolizable energy, Kcal/kg & $2,796.00$ \\
Digestible protein, g/kg & 304.50 \\
Digestible organic matter, g/kg & 586.70 \\
\hline
\end{tabular}

${ }^{1}$ Metabolization coefficient.

The small differences could be related to the origin of the CM in different studies as well as the level of fiber of the meals, which can negatively influence the digestibility, as more fibrous food reduces the digestibility of certain nutrients.

The CM reported by Rostagno et al. (2011) contained a higher CF level (112 g/kg) compared to that of the meal used for this experiment (72 g/kg). In other studies, similar values of nutrient content were reported, while Bell (1984) quoted values for digestible and metabolizable energy of 2,950 and $2,770 \mathrm{kcal} / \mathrm{kg}$, respectively.

In general, the value of digestible and metabolizable energy of CM is smaller than that of soybean meal, which has a level of 3,154 kcal ME/ $\mathrm{kg}$ (ROSTAGNO et al., 2011). This can be explained mainly due to the high levels of fiber of the CM, which is three times greater than those found in soybean meal (121 g/kg and $34 \mathrm{~g} / \mathrm{kg}$, respectively). In contrast to soybean meal, the shells remain in the canola meal, totaling approximately $30 \%$ of its composition, comprising the main limiting factor to the use of CM in diets for pigs (BELL, 1993).

The digestibility of amino acids for CM found in experiment II (Table 5) were generally lower than those observed by Rostagno et al. (2011), who reported digestibility values above 0.75 for all amino acids. 
Table 5. Apparent ileal digestibility coefficients (AIDC) and true (TIDC) of crude protein and amino acids of canola meal, average values endogenous ileal amino acid, determined with the one protein-free diet (OFD) for pigs, total amino acids (TAA) and true digestibility amino acids (TDAA) of canola meal.

\begin{tabular}{lccccc}
\hline & AIDC, $\mathrm{g} / \mathrm{g}$ & TIDC, $\mathrm{g} / \mathrm{g}$ & OFD $\mathrm{mg} / \mathrm{g}$ & TAA, $/ \mathrm{kg}$ & TDAA, $\mathrm{g} / \mathrm{kg}$ \\
\hline CP, g/g & 0.501 & 0.655 & - & & \\
\hline Essential amino acids & & & & & \\
\hline Arginine & 0.705 & 0.799 & 8.70 & 25.20 & 20.20 \\
Phenylalanine & 0.579 & 0.642 & 2.80 & 14.20 & 9.10 \\
Histidine & 0.666 & 0.720 & 1.40 & 9.00 & 6.50 \\
Isoleucine & 0.609 & 0.651 & 1.90 & 13.40 & 8.70 \\
Leucine & 0.632 & 0.675 & 3.50 & 23.30 & 15.70 \\
Lysine & 0.676 & 0.702 & 1.50 & 16.80 & 11.80 \\
Methionine + cystine & 0.780 & 0.816 & 1.40 & 11.10 & 9.10 \\
Threonine & 0.430 & 0.566 & 4.00 & 14.00 & 7.90 \\
Tryptophan & 0.506 & 0.592 & 1.50 & 4.10 & 2.40 \\
Valine & 0.587 & 0.635 & 2.70 & 16.60 & 10.60 \\
\hline Non-essential amino acids & & & & & \\
\hline Alanine & 0.548 & 0.662 & 6.10 & 16.40 & 10.80 \\
Aspartic acid & 0.578 & 0.611 & 2.80 & 25.70 & 15.70 \\
Glutamic acid & 0.699 & 0.728 & 6.00 & 63.60 & 46.30 \\
Glycine & 0.382 & 0.599 & 12.40 & 17.90 & 10.70 \\
Serine & 0.517 & 0.616 & 4.00 & 15.00 & 9.20 \\
Tyrosine & 0.577 & 0.630 & 1.70 & 10.70 & 6.70 \\
\hline
\end{tabular}

Myrie et al. (2008) reported the highest apparent ileal digestibility coefficients (AIDC) for histidine, tyrosine and glutamic acid $(0.928,0.942$ and 0.934 , respectively) and the lowest for threonine and glycine (0.855 and 0.757 , respectively). Similar behavior was reported by Stein et al. (2005), who observed higher values of AIDC for tryptophan, arginine and glutamic acid (0.864, 0.848 and 0.844, respectively) and lower for threonine and glycine (0.727 and 0.719 , respectively).

Moreover, the smaller values for the AIDC of protein and amino acids of CM seen in this study were similar to those reported by Mariscal et al. (2009) who reported low AIDC for most amino acids, ranging from $40 \%$ to $60 \%$. The reduction in digestibility coefficients of protein and amino acids can be attributed to the high levels of fiber contained in $\mathrm{CM}$ compared to other, more digestible protein sources (MINKOWSKI, 2002).

However, a similar behavior in AIDC to the present study was shown in some CM studies (STEIN et al., 2005; MYRIE et al., 2008; WOYENGO et al., 2010). With a low AIDC of amino acids, there is a tendency for values of met + cys $(0.779)$ and arginine $(0.705)$ to increase and the values for threonine (0.430), glycine $(0.382)$ and serine $(0.517)$ to decrease.

The low coefficient of digestibility of threonine may be explained by the high concentration of mucin in the intestinal mucosa (FULLER, 1994) or by its low rate of absorption (FAN et al., 1995).

The low digestibility coefficient of glycine may be related to the fact that this amino acid is present in a relatively high proportion in endogenous protein, representing about $13 \%$ of the level of endogenous amino acids in ileal digesta (SAUER et al., 1977).

In a study performed by Woyengo et al. (2010), it was also observed that all of the values for TIDC of the CM protein and amino acids were higher in comparison with the present study (Table 5), with higher values observed for arginine, phenylalanine 
and glutamic acid (0.862; 0.904 and 0.869, respectively) and lower values for threonine and aspartic acid (0.721 and 0.750, respectively). Also, Stein et al. (2005) and Myrie et al. (2008) reported values of true ileal digestibility coefficients (TIDC) for CM crude protein and amino acids that were higher in comparison to those found in this experiment.

The lowest AIDC and TIDC of glycerin, serine, and threonine, can mainly explained by their relatively high concentrations in endogenous secretions.

According to Souffrant (2001), glycine is a major constituent of bile salts, constituting more than $90 \%$ of the total content of amino acids secreted in the bile juice of pigs. The majority of the endogenous protein is derived from the deconjugation of bile salts and mucoglycoproteins. Such components are generally resistant to the action of proteolytic enzymes and therefore do not suffer resorption (FONTES et al., 2007).

The low digestibility of threonine may be partly due to its low rate of absorption in the small intestine (MARISCAL et al., 2009). Furthermore, according to Fan et al. (1995), based on the specificity of the endogenous proteases and peptidases, threonine is the last amino acid to be released by enzymatic hydrolysis of proteins.

In general, the lowest values for AIDC and TIDC of $\mathrm{CM}$ proteins and amino acids of the present work may be associated with high content of antinutritional factors present in the shell of the canola, especially tannins (BELL, 1993). Jansman (1993) reported that condensed tannins may decrease the digestibility of $\mathrm{CP}$ and amino acids by different mechanisms, including the formation of hydrogen bonds and hydrophobic interactions of its hydroxyl groups with the carboxyl groups of dietary proteins. Therefore, there is a decrease of enzyme activity, and a decrease of the transmembrane absorption of nutrients, along with an increase of the secretion of endogenous proteins.
Minkowski (2002) attributed the reduction of AIDC and TIDC of CM to its high fiber content. Likewise, Pozza et al. (2003) showed that the canola fiber (NDF) considerably influenced the ileal endogenous losses of nitrogen in pigs, since these compounds are not digested by intestinal enzymes.

Feedstuffs with the levels of pectins considered here decrease the AIDC and TIDC by altering the properties of viscosity and gelation of digesta, which decrease the digestion and absorption of nutrients by reducing the mixing of intestinal contents. Therefore, interfering with the enzymesubstrate union and forming a water static film establishing a physical barrier to absorption of nutrients (ANDERSON et al., 1990). The protein content, which is within the fiber fraction (cell wall components) and accounts for about $22.5 \%$, may be of low availability and reduce the average digestibility coefficients of the food, since the union with the fiber fraction hinders the action of digestive enzymes (BELL, 1993).

According to Fontes et al. (2007), differences in the composition and digestibility of amino acids in CM may be due to several factors such as grain variety, level of fertilization and climatic conditions, all of which can change the total and relative amounts of the major seed proteins (albumin, globulin, prolamins and glutenins), resulting in changes in the digestibility of amino acids (SAUER; OZIMEK, 1986).

The absolute values of the ileal endogenous losses in the fluid (Table 5) were determined using an OFD. The high glutamic acid content in the ileal endogenous secretion can be explained by a relative proportion of this acid in the pancreatic juice of pigs (POHLAND et al., 1993). Similarly, the arginine and threonine levels may be associated with the increase of glycoproteins from the intestinal mucus, which is rich in these amino acids (GRALA et al., 1998). A high amount of glycine in the endogenous secretion is due to the fact that this amino acid makes up about $90 \%$ of all amino acids in bile 
and mucoglicoproteins (HUANG et al., 1999). Threonine, serine and proline are the amino acids that are found in greater quantities in endogenous losses in the form of mucus, which is in the range of 20 to $30 \%$ in pigs (LIEN, 1995). Components of the diet can alter the normal secretion of mucus, intestine, and anti-nutritional factors that increase the production of mucin, which is mainly composed of threonine (LAMONT, 1992).

The difference between the total amino acid content and digestible amino acid content of CM (Table 5) should be considered in the diet formulation, since values for digestible amino acid requirements can be found in the literature (NRC, 2012; ROSTAGNO et al., 2011).

In experiment III, the regression analysis indicated that there no effect $(\mathrm{P} \geq 0.05)$ of inclusion level of CM on the DFI (Daily feed intake), DWG (Daily weight gain) and feed:gain ratio variables and PUN (Table 6). It should be noted that the diets were formulated to be isonutritive and isocaloric, and that anti-nutritional factors are not too high to degrade performance. Its negative effects have been corrected in the formulation with digestible nutrients.

Table 6. Performance and Plasma Urea Nitrogen of piglets, fed diets with canola meal.

\begin{tabular}{|c|c|c|c|c|c|c|c|c|c|}
\hline \multirow[b]{2}{*}{ Item } & \multicolumn{5}{|c|}{ Inclusion level of Canola meal (g/kg) } & \multirow[b]{2}{*}{$\operatorname{Mean} \pm \mathrm{SE}^{1}$} & \multirow[b]{2}{*}{$\mathrm{CV}^{2}, \%$} & \multirow[b]{2}{*}{$\operatorname{Lin}^{3}$} & \multirow[b]{2}{*}{ Qua $^{4}$} \\
\hline & 0 & 50 & 100 & 150 & 200 & & & & \\
\hline $\mathrm{DFI}^{5}, \mathrm{~kg}$ & 1.26 & 1.21 & 1.17 & 1.24 & 1.11 & $1.21 \pm 0.12$ & 10.33 & NS & NS \\
\hline $\mathrm{DWG}^{5}, \mathrm{~kg}$ & 0.68 & 0.67 & 0.65 & 0.70 & 0.59 & $0.66 \pm 0.08$ & 12.57 & NS & NS \\
\hline $\mathrm{FGR}^{5}$ & 1.86 & 1.82 & 1.82 & 1.79 & 1.87 & $1.83 \pm 0.12$ & 6.44 & NS & NS \\
\hline $\mathrm{PUN}^{5}, \mathrm{mg} / \mathrm{dl}$ & 11.30 & 11.90 & 12.90 & 12.70 & 11.70 & $12.1 \pm 1.99$ & 16.38 & NS & NS \\
\hline
\end{tabular}

${ }^{1}$ Standard error; ${ }^{2}$ Variation coefficient; ${ }^{3}$ Linear effect of the levels of canola meal; ${ }^{4}$ Quadratic effect of the levels of canola meal, ${ }^{5} \mathrm{DFI}=$ Daily feed intake; $\mathrm{DWG}=$ Daily weight gain; FGR = Feed:Gain ratio; PUN = Plasma Urea Nitrogen; NS = not significant.

The results obtained for the performance variables (DFI, DWG, FGR) suggested that the availability of digestible nutrients from diets with various inclusion levels were kept close together, which can be confirmed by the PUN results, which were not affected $(P \geq 0.05)$ in this study and reflect the appropriate amino acid supply in both quantity and quality (COMA et al., 1995).

The results of this study are similar to those obtained by Zanotto et al. (2009), who found no effect of the inclusion level of CM on the DWG and DFI, suggesting that CM can replace up to $40 \%$ of soybean meal in diets for growing pigs. However, the current results are different to those reported by Moreira et al. (1995), which indicated that the inclusion of $\mathrm{CM}(0,40,80$ and $120 \mathrm{~g} / \mathrm{kg})$ did not affect the DFI, but reduced the DWG and had a quadratic effect on FGR, and concluded that the level of $84.4 \mathrm{~g} / \mathrm{kg} \mathrm{CM}$ was the best at an early stage.
On the other hand, Baidoo et al. (1987) observed a reduction in consumption with the inclusion of $\mathrm{CM}$ in diets for piglets.

Roth-Maier et al. (2004) determined that a partial replacement of soybean meal by CM increases the DWG compared to diets with soybean meal or with CM alone.

According to CCC (2009), the inclusion levels of $\mathrm{CM}$ in the diets should be limited for piglets $(6-20 \mathrm{~kg})$ as there is a tendency to decrease the DWG with an increase of the inclusion of CM. They recommend the inclusion of up to $50 \mathrm{~g} / \mathrm{kg}$ of this food in the piglets' diets. The performance of piglets can be influenced by fiber levels, presence of tannins, sinapine and glucosinolates in the meal (BOURDON; AUMAITRE, 1990; LEE; HILL, 1983), which can change depending on the origin and processing. 
The results of the economic analysis (Table 7) showed that the cost of feed per kilogram of body weight gain was maintained $(\mathrm{P} \geq 0.05)$ with increased $\mathrm{CM}$ inclusion levels in the diet. No significant differences $(\mathrm{P} \geq 0.05)$ were observed between the inclusions levels of CM compared to the control diet (zero inclusion level of CM).

Table 7. Economic analysis of using canola meal on starting pigs feeding.

\begin{tabular}{|c|c|c|c|c|c|c|c|c|}
\hline \multirow{2}{*}{ Items } & \multicolumn{5}{|c|}{ Inclusion levels of canola meal $(\mathrm{g} / \mathrm{kg})$} & \multirow[b]{2}{*}{$\mathrm{CV}^{4}$} & \multirow[b]{2}{*}{ Dun $^{5}$} & \multirow[b]{2}{*}{ Reg } \\
\hline & 0 & 50 & 100 & 150 & 200 & & & \\
\hline Initial weight, kg & 15.05 & 15.11 & 15.12 & 15.07 & 15.06 & - & - & - \\
\hline Final weight, kg & 30.81 & 30.65 & 30.04 & 31.18 & 28.62 & - & - & - \\
\hline Diet cost, $\mathrm{R} \$ / \mathrm{kg}$ & 0.62 & 0.62 & 0.63 & 0.63 & 0.64 & - & - & - \\
\hline $\mathrm{FC}, \mathrm{R} \$ / \mathrm{kg} \mathrm{BW}^{1}$ & 1.15 & 1.13 & 1.14 & 1.13 & 1.18 & 6.42 & $\mathrm{P} \geq 0.05$ & NS \\
\hline $\mathrm{EEI}^{2}$ & 98.37 & 100.00 & 98.88 & 99.67 & 95.55 & - & - & - \\
\hline $\mathrm{IC}^{3}$ & 101.60 & 100.00 & 101.10 & 100.30 & 104.60 & - & - & - \\
\hline
\end{tabular}

${ }^{1}$ Feed cost per kg of body weight gain; ${ }^{2}$ Economic efficiency index; ${ }^{3}$ Index cost; ${ }^{4}$ Coefficient of variation; ${ }^{5}$ Dunnett's test; $*$ different value $(\mathrm{P}<0.05)$ in relation to level 0.0 inclusion, $\mathrm{NS}=$ not significant; ${ }^{6}$ Regression Analysis.

The economic analysis indicated that the use of up to $200 \mathrm{~g} / \mathrm{kg} \mathrm{CM}$ in isoenergetic diets can be used without reducing or increasing the feeding cost of piglets $(15-30 \mathrm{~kg})$ compared to the diet without CM.

\section{Conclusions}

The values of digestible and metabolizable energy (as-fed basis) for canola meal are 2,995 and $2,796 \mathrm{kcal} / \mathrm{kg}$ for starting pigs $(15-30 \mathrm{~kg})$, respectively. The values of digestible essential amino acids of canola meal are: lysine $11.8 \mathrm{~g} / \mathrm{kg}$; methionine+cystine $9.1 \mathrm{~g} / \mathrm{kg}$; threonine $7.9 \mathrm{~g} / \mathrm{kg}$; tryptophan $2.4 \mathrm{~g} / \mathrm{kg}$; leucine $15.7 \mathrm{~g} / \mathrm{kg}$; isoleucine $8.7 \mathrm{~g} / \mathrm{kg}$; and valine $10.6 \mathrm{~g} / \mathrm{kg}$.

Using up to $200 \mathrm{~g} / \mathrm{kg}$ of canola meal does not impair the performance of starting pigs (15-30 kg). However, the economic feasibility of its use depends on the price relationship among the feedstuffs, in particular soybean meal and synthetic amino acids (or other protein sources).

\section{Acknowledgements}

We thank BR-Foods for providing the Canola meal and PEC-PG/CNPq for the scholarship and research grant.

\section{References}

ANDERSON, J. W.; DEAKINS, D. A.; FLOORE, T. L.; SMITHE, B. M.; WHITIS, S. E. Dietary fiber and coronary heart disease. Critical Reviews in Food Science and Nutrition, Lexington, v. 29, n. 2, p. 95-147, 1990.

ASSOCIATION OF OFFICIAL ANALYTICAL CHEMISTS - AOAC. 1990. Official methods of analysis. 16. ed. Arlington: AOAC International, $1136 \mathrm{p}$.

BAIDOO, S. K.; MITARU, B. N.; AHERNE, F. X.; BLAIR, R. Canola meal as a protein supplement for growing-finishing pigs. Animal Feed Science and Technology, Amsterdam, v. 18, n. 1, p. 37-44, 1987.

BELLAVER, C. Estimation of amino acid digestibility and its usefulness in swine feed formulation. 1989. Thesis ( $\mathrm{PhD}$ in Animal Science) - University of Illinois, Urbana Champaign.

BELlAVER, C.; FIALHO, E. T.; PROTAS, J. F. S.; GOMES, P. C. Radícula de malte na alimentação de suínos em crescimento e terminação. Pesquisa Agropecuária Brasileira, Brasília, v. 20, n. 8, p. 969-974, 1985. 
BELL, J. M. Factors affecting the nutritional value of canola meal: a review. Canadian Journal of Animal Science, Ottawa, v. 73, n. 4, p. 326-333, 1993.

BELL, J. M. Nutrients and toxicants in rapeseed meal: a review. Journal of Animal Science, Madison, v. 58, n. 4, p. 996-1010, 1984.

BELL, J. M.; KEITH, M. O. A survey of variation in the quimical composition of commercial canola meal produced in Western Canadian crushing plants. Canadian Journal of Animal Science, Saskatoon, v. 71, n. 2, p. 469480, 1991.

BOURDON, D.; AUMAITRE, A. Low glucosinolate rapeseeds and rapeseed meals: effect of technological treatments on chemical composition, digestible energy content and feeding value for growing pigs. Animal Feed Science and Technology, Amsterdam, v. 30, n. 3, p. 175191, 1990.

CAI, Y.; ZIMMERMAN, D. R.; EWAN, R. C. Diurnal variation in concentrations of plasma urea nitrogen and amino acids in pigs given free access to feed or fed twice daily. Journal Nutrition, Ames, v. 124, n. 7, p. 10881093, 1994.

CANOLA COUNCIL OF CANADA - CCC. Canadian canola meal: maximum inclusion rates. Canola Council of Canada. Winnipeg: Edited by: Canadian International Grains Institute, 2009. 48 p.

CASTELL, A. G.; CLIPLEF, R. L. Evaluation of pea screenings and canola meal as a supplementary protein source in barley - based diets fed to growing-finishing pigs. Canadian Journal Animal Science, BrandonManitoba, v. 73, n. 1, p. 129-139, 1993.

COMA, J.; CARRION, D.; ZIMMERMAN, D. R. Use of plasma urea nitrogen as a rapid response criterion to determine the lysine requirement of pigs. Journal of Animal Science, Champaign, v. 73, n. 2, p. 472-481, 1995.

FAN, M. Z.; SAUER, W. C.; DE LANGE, C. M. F. Amino acid digestibility in soybean meal, extruded soybean and full-fat canola for early- weaned pigs. Animal Feed Science and Technology, Amsterdam, v. 52, n. 4, p. 189203, 1995.

FONTES, D. O.; DONZELE, J. L.; MASCAREHAS, A. G.; APOLÔNIO, L. R.; SILVA, F. C. O.; FONTES, F. A. P. V.; CORRÊA, G. S. S. Composição aminoácidica e digestibilidade ileal de aminoácidos de alimentos energéticos. Arquivo Brasileiro de Medicina Veterinária e Zootecnia, Belo Horizonte, v. 59, n. 1, p. 196-202, 2007.
FULLER, M. F. Amino acids requirements for maintenance, body protein accretion and reproduction in pigs. In: D'MELLO, J. P. F. Amino acids in farm animal nutrition. Edinburgh: The Scottish Agricultural College, 1994. p. 155-184.

GOMES, M. F. M.; BARBOSA, H. P.; FIALHO, E. T.; FERREIRA, E. T.; LIMA, G. J. M. Análise econômica da utilização de triguilho para suínos. Concórdia: EMBRAPA-CNPSA, 1991.p. 1-2. (Comunicado técnico, 179).

GRALA, W.; VERSTEGEN, M. W. A.; JANSMAN, A. J. M.; HUISMAN, J.; LEEUSEN, P. Ileal apparent protein and amino acid digestibilities and endogenous nitrogen losses in pigs fed soybean a rapeseed products. Journal of Animal Science, Champaign, v. 76, n. 2, p. 557-568, 1998.

HUANG, S. X.; SAUER, W. C.; MARTY, B.; HARDIN, R. T. Amino acid digestibilities in different samples of wheat shorts for growing pigs. Journal of Animal Science, Champaign, v. 77, n. 9, p. 2469-2477, 1999.

JANSMAN, A. J. M. Tannins in feedstuffs for simplestomached animals. Nutrition Research Reviews, Wageningen, v. 6, n. 1, p. 209-236, 1993.

JOHNSTON, L. J.; NOLL, S.; RENTERIA, A. ASHURSON, J. Feeding by-products high in concentration of fiber to non-ruminants. In: NATIONAL SYMPOSIUM ON ALTERNATIVE FEEDS FOR LIVESTOCK AND POULTRY HELD IN KANSAS CITY, 3., 2003, Kansas City. Proceedings... Kansas City: [s.n], 2003. p. 1-26.

LAMONT, J. T. Mucus: the frontline of intestinal mucosal defense. Annals of the New York Academy of Sciences, Boston, v. 664, n. 1, p. 190-201, 1992.

LEE, P. A.; HILL, R. Voluntary intake of growing pigs given diets containing rapeseed meal from different types and varieties of rape as the only protein supplement. British Journal of Nutrition, London, v. 50, n. 3, p. 661671, 1983.

LIEN, K. A. Endogenous protein in ileal digesta: estimation of the mucin content and evaluation of the $15 \mathrm{~N}$-isotope dilution technique. 1995. Thesis (Doctor of Philosophy) - Department of Animal Science. University of Alberta. Edmonton, Canada.

MARISCAL, G.; REIS, T. S.; PARRA, J. Digestibilidad ileal aparente de la proteína y aminoácidos de la torta de canola en lechones recién destetados. Revista Medicina Veterinaria y Zootecnia de Córdoba, Montería, v. 14, n. 1, p. 1544-1553, 2009. 
MATTERSON, L. D.; POTTER, L. M.; STUTZ, M. W. The metabolizable energy of feed ingredients for chickens. University of Connecticut, Agricultural Experiment Station. Research Report, Storrs, Connecticut. v. 7, n. 1, p. 11-14, 1965.

MINKOWSKI, K. Influence of dehulling of rape seed on chemical composition of meal. Animal Feed Science and Technology, Amsterdam, v. 96, n. 4, p. 237-244, 2002.

MOREIRA, I.; FURLAN, A. C.; SCAPINELLO, C.; MURAKAMI, A. Utilização do farelo de canola na alimentação de suínos na fase inicial (42 a 63 dias). Revista Brasileira de Zootecnia, Viçosa, MG, v. 24, n. 3, p. 417-427, 1995.

MOREIRA, I.; MARANGONI, I.; FURLAN, A. C.; SCAPINELLO, C.; MARTINS, E.; MURAKAMI, A. E. Utilização do farelo de canola na alimentação de suínos na fase total de crescimento e terminação (61 a 141 dias). Revista Brasileira de Zootecnia, Viçosa, MG, v. 25, n. 4, p. 697-712, 1996.

MYRIE, S. B.; BERTOLO, R. F.; SAUER, W. C.; BALL, R. Effect of common antinutritive factors and fibrous feedstuffs in pig diets on amino acid digestibilities with special emphasis on threonine. Journal of Animal Science, Champaign, v. 86, n. 3, p. 609-619, 2008.

NÄSI, M.; SILJANDER-RASI, H. Effects of thermal processing on digestibility and protein utilization of rapeseed meal of medium and low glucosinolate type in diets for growing pigs. Journal of Agricultural Science, Cambridge, v. 63, n. 2, p. 475-482, 1991.

NUTRIENT REQUIREMENTS OF SWINE - NRC. 11. ed. Washington, DC: National Academy, 2012. 400p.

PEKAS, J. C. Versatile swine laboratory apparatus for physiologic and metabolic studies. Journal of Animal Science, Champaign, v. 27, n. 5, p. 1303-1309, 1968.

POHLAND, U.; SOUFFRANT, W. C.; SAUER, W. C. MOSENTHIN, R.; DE LANGE, C. F. Effect of feeding different diets on the exocrine pancreatic secretion of nitrogen, amino acids and enzymes in growing pigs. Journal of the Science of Food and Agriculture, Alberta, v. 62 , n. 3, p. 229-237, 1993.

POZZA, P. C.; GOMES, P. C.; ROSTAGNO, H. S.; DONZELE, J. L.; SANTOS, M. S. dos; FERRERIRA, R. A. Avaliação da perda endógena de aminoácidos, em função de diferentes níveis de fibra para suínos. Revista Brasileira de Zootecnia, Viçosa, MG, v. 32, n. 6, p. 13541361, 2003.
ROJO, G. A.; PEREZ, M. V. G.; BAYARDO, U. A.; CORREA, H. J. C.; CUARÓN, J. A. I. Canola meal as a protein supplement in diets for finishing pigs. Técnico Pecuario Méxicano, Tulancingo, v. 39, n. 2, p. 179-192, 2001.

ROSTAGNO, H. S.; ALBINO, L. F. T.; DONZELE, J. L.; GOMES, P. C.; OLIVEIRA, R. F.; LOPEZ, D. C.; FERRERIRA, A. S.; TOLEDO, S. L. B. Tabelas brasileiras para aves e suínos: composição de alimentos e exigências nutricionais. 2. ed. Viçosa: UFV, 2005. 186 p.

ROSTAGNO, H. S.; ALBINO, L. F. T.; DONZELE, J. L.; GOMES, P. C.; OLIVEIRA, R. F.; LOPEZ, D. C.; FERRERIRA, A. S.; EUCLIDES, R. F. Tabelas brasileiras para aves e suínos: composição de alimentos e exigências nutricionais. 3. ed. Viçosa: UFV, 2011. 252 p.

ROTH-MAIER, D. A.; BÖHMER, B. M.; ROTH, F. X. Effects of feeding canola meal and sweet lupin (L. luteus, L. angustifolius) in amino acid balanced diets on growth performance and carcass characteristics of growingfinishing pigs. Animal Research, Munich, v. 53, n. 1, p. 21-34, 2004.

SAKOMURA, N. K.; ROSTAGNO, H. S. Métodos de pesquisa em nutrição de monogástricos. Jaboticabal: Funep, 2007. 283 p.

SAMPAIO, I. B. M. Estatística aplicada a experimentação animal. Belo Horizonte: Universidade Federal de Minas Gerais, 1998. 221 p.

SAUER, W. C.; STOTHERS, S. C.; PHILLIPS, G. D. Apparent availabilities of amino acids in corn, wheat and barley for growing pigs. Canadian Journal of Animal Science, Champaign, v. 57, n. 3, p. 585-597, 1977.

SAUER, W. C.; OZIMEK, L. Digestibility of amino acid in swine: results and their practical applications. a review. Livestock Production Science, Alberta, v. 15, n. 4, p. 367-388, 1986.

SENEVIRATNE， R. W.; YOUNG, M. G.; BELTRANENA, L. A.; GOONEWARDENE, L. A.; NEWKIRK, R. W.; ZIJLSTRA, R. T. The nutritional value of expeller-pressed canola meal for grower-finisher pigs. Journal of Animal Science, Champaign, v. 88, n. 6, p. 2073-2083, 2010.

SILVA, D. J.; QUEIROZ, A. C. Análise de alimentos: métodos químicos e biológicos. 3. ed. Viçosa, MG: Universidade Federal de Viçosa, 2002. 235 p.

SORREL, E. R.; SHURSON, G. C. Use of canola and canola meal in swine diets reviewed. Feedstuffs, Minneapolis, v. 62, n. 14, p. 13-16, 1992. 
SOUFFRANT, W. B. Effect of dietary fiber on ileal digestibility and endogenous nitrogen losses in the pig. Animal Feed Science and Technology, Amsterdam, v. 90, n. 1, p. 93-102, 2001.

SOUZA, A. L. P. Assessment of dietary enzyme supplementation on ileal and total tract digestibilities in gestanting and lactanting swine. 2003. Thesis $(\mathrm{PhD}$ in Animal Science) - University of Kentucky, Lexington.

STEIN, H. H.; PEDERSEN, C.; WIRT, A. R.; BOHLKE, R. A. Additivity of values for apparent and standardized ileal digestibility of amino acids in mixed diets fed to growing pigs. Journal of Animal Science, Champaign, v. 83, n. 10, p. 2387-2395, 2005.

THACKER, P. A.; NEWKIRK, R. W. Performance of growing-finishing pigs fed barley-based diets containing toasted or non-toasted canola meal. Canadian Journal of Animal Science, Saskatoon, v. 85, n. 1, p. 53-59, 2005.
WILLIAMS, P. R. V. Digestible amino acids for nomruminant animals: theory and recent challenges. Animal Feed Science and Technology, Amsterdam, v. 53, n. 2, p. 173-187, 1995.

WOYENGO, T. A.; KIARIE, E.; NYACHOTI, C. M. Energy and amino acid utilization in expeller-extracted canola meal fed to growing pigs. Journal of Animal Science, Champaign, v. 88, n. 4, p. 1433-1441, 2010.

ZANOTTO, D.; LUDKE, J. V.; GUIDONI, A. L.; GOMES, P. C.; BRUM, P. A. R.; AJALA, L. C. Utilização do farelo de canola na alimentação de suínos em crescimento e terminação. Archivos de Zootecnia, Córdoba, v. 58, n. 224, p. 717-728, 2009. 